УДК 008: [17.022.1: 159.928

\author{
Gavelya Oksana, \\ Candidate of Pedagogical Sciences, Associate \\ Professor, Professor of the Department \\ of Humanities National Academy of Managerial Staff \\ of Culture and Arts \\ ORCID 000-0002-7871-6813 \\ o.gavelya@ukr.net \\ Shkil Svitlana, \\ Doctor of Philosophical Sciences, Professor of the \\ Department of Philosophy, National University \\ of Life and Environmental \\ Sciences of Ukraine \\ ORCID 0000-0003-3859-816X \\ lauby@meta.ua
}

\title{
THE CULTURAL VALUES OF THE GIFTED PERSONALITY IN THEIR TRADITIONAL AND PLURAL REPRESENTATIONS
}

The purpose of the work is to determine the typological features of a gifted person from the standpoint of its participation in traditional and innovative cultural and artistic activities. Methodology of the research is based on application of activity, criticalanalytical, structural-functional and subject-axiological approach to revealing the specialization and existing reciprocity between different types of traditional and innovative cultural and artistic activities, to study the cultural values of gifted personality in traditional and plural representations. The scientific novelty of the work lies in identification of the specialization and the existing reciprocity between different types of traditional and innovative cultural and artistic activities; in defining the typology of people involved in the creation, dissemination and preservation of cultural property; in the study of the cultural values of gifted personality in traditional and plural representations. Conclusion. Based on the specialization and the existing reciprocity between different types of traditional and innovative cultural and artistic activities, the spiritual, intellectual, creative and entrepreneurial abilities of a gifted person involved in it, we identified six types of people: the creators of cultural values that create artistic culture and television products; substantial figures, who perform a certain prognostic function in society; people of real action, who are involved in the organization and development of the material infrastructure of culture (in these three types of cultural values are represented predominantly in traditional representations); virtual fashion designers, who display a predominantly postmodern view of the world and simulate virtual reality; merchants with essential goods engaged in the production of material goods and their timely delivery to consumers (these two types are dominated by plural representations of cultural values); a progression that seeks to tighten the cultural development of society to a higher level (its cultural values are represented both in traditional and plural representations). Defined representations of the cultural values of gifted personality direct scientists to deepen the idea of self-identification of a person in cultural and artistic activity.

Key words: cultural values, gifted personality, traditional representations, plural representations, reciprocity, specialization, innovative cultural and artistic activity, creator of cultural values, person of real action, virtual designer, merchant with essential goods, progressor.

Гавеля Оксана Миколаївна, кандидат педагогічних наук, доцент, доцент кафредри гуманітарних дисциплін Національної академії керівних кадрів культури і мистецтв; Шкіль Світлана Олександрівна, доктор фрілософрських наук, доцент, профресор кафредри фрілософрії Національного університету біоресурсів і природокористування України

Культурні цінності обдарованої особистості у їх традиційних і плюральних репрезентаціях

Мета роботи полягає у визначенні типологічних особливостей обдарованої особистості з позицій її участі в традиційній та інноваційній культурно-мистецькій діяльності. Методологія дослідження: базується на застосуванні діяльнісного, критичноаналітичного, структурно-функціонального та предметно-аксіологічного підходу до виявлення спеціалізації та існуючої реципрокності між різними видами традиційної та інноваційної культурно-мистецької діяльності, до вивчення культурних цінностей обдарованої особистості у традиційних і плюральних репрезентаціях. Наукова новизна роботи полягає у виявленні спеціалізації та існуючої реципрокності між різними видами традиційної та інноваційної культурно-мистецької діяльності; у визначенні типології людей, які беруть участь у створенні, поширенні і збереженні культурних цінностей; у дослідженні культурних цінностей обдарованої особистості у традиційних і плюральних репрезентаціях. Висновок. Спираючись на спеціалізацію та на існуючу реципрокність між різними видами традиційної та інноваційної культурно-мистецької діяльності, на задіяні в ній духовні, інтелектуальні, творчі і підприємницькі здібності обдарованої особистості, нами було визначено шість типів людей: творці культурних цінностей, які створюють художню культуру та телевізуальні продукти; субстанціональні діячі, які виконують у суспільстві певну прогностичну функцію; люди реальної дії, які займаються організацією та розвитком матеріальної інфраструктури культури (в цих трьох типів культурні цінності представлено переважно у традиційних репрезентаціях); віртуальні модельєри, які виявляють переважно постмодерний погляд на світ і моделюють віртуальну реальність; торговці насущними благами, які займаються виробництвом культурних послуг і товарів, а також своєчасною їх доставкою споживачам (у цих двох типів переважають плюральні репрезентації культурних цінностей); прогресор, який прагне підтягнути культурний розвиток суспільства до вищого рівня (його культурні цінності представлені як у традиційних, так і плюральних репрезентаціях). Визначені в досліджені репрезентації культурних цінностей обдарованої особистості спрямовують науковців на поглиблення уявлення про самоідентифікацію людини в культурно-мистецькій діяльності.

Ключові слова: культурні цінності, обдарована особистість, традиційні репрезентації, плюральні репрезентації, реципрокність, спеціалізація, інноваційна культурно-мистецька діяльність, творець культурних цінностей, людина реальної дії, віртуальний модельєр, торговець насущними благами, прогресор.

Гавеля Оксана Николаевна, кандидат педагогических наук, доцент, доцент кафредры гуманитарных дисциплин Национальной академии руководящих кадров культуры и искусств; Шкиль Светлана Александровна, доктор

(c) Gavelya O., 2019

(C) Shkil S., 2019 
философских наук, доцент, профрессор кафедры фрилософии Национального университета биоресурсов и природопользования Украины

Культурные ценности одаренной личности в их традиционных и плюральных репрезентациях

Цель работы заключается в определении типологических особенностей одаренной личности с позиций ее участия в традиционной и инновационной культурно-художественной деятельности. Методология исследования: базируется на применении деятельного, критически-аналитического, структурно-функционального и предметно-аксиологического подхода к выявлению специализации и существующей реципрокности между разными видами традиционной и инновационной культурно-художественной деятельности, к изучению культурных ценностей одаренной личности в традиционных и плюральных репрезентациях. Научная новизна работы заключается в выявлении специализации и существующей реципрокності между разными видами традиционной и инновационной культурно-художественной деятельности; в определении типологии людей, которые участвуют в создании, распространении и сохранении культурных ценностей; в исследовании культурных ценностей одаренной личности в традиционных и плюральных репрезентациях. Выводы. Опираясь на специализацию и на существующую реципрокность между разными видами традиционной и инновационной культурно-художественной деятельности, на задействованные в ней духовные, интеллектуальные, творческие и предпринимательские способности одаренной личности, нами было определено шесть типов людей: творцы культурных ценностей, которые создают художественную культуру и телевизуальные продукты; субстанциональные деятели, которые выполняют в обществе определенную прогностическую функцию; люди реального действия, которые занимаются организацией и развитием материальной инфраструктуры культуры (у этих трех типов культурные ценности представлены преимущественно в традиционных репрезентациях); виртуальные модельеры, которые обнаруживают преимущественно постмодерный взгляд на мир и моделируют виртуальную реальность; торговцы насущными благами, которые занимаются производством культурных услуг и товаров, а также своевременной их доставкой потребителям (у этих двух типов преобладают плюральные репрезентации культурных ценностей); прогресор, который стремится подтянуть культурное развитие общества до высшего уровня (его культурные ценности представлены как в традиционных, так и плюральных репрезентациях). Определенные в исследовании репрезентации культурных ценностей одаренной личности направляют ученых на углубление представления о самоидентификации человека в культурно-художественной деятельности.

Ключевые слова: культурные ценности, одаренная личность, традиционные репрезентации, плюральные репрезентации, реципрокность, специализация, инновационная культурно-художественная деятельность, творец культурных ценностей, человек реального действия, виртуальный модельер, торговец насущными благами, прогресор.

Relevance of research topic. The transformation of the cultural values of gifted personality in the context of the challenges of globalization requires that they be adequately studied in plural representations. In various objects of material and spiritual culture, having artistic, historical, ethnographic and scientific significance, in the original artistic works of painting, graphics and sculptures, artistic compositions, works of decorative and applied and traditional folk art, museum exhibits, works of musical art, books, family values represent the traditional perception of reality by a gifted personality. It is accompanied by its artistic taste, as well as the emotional and expressive language, through which cultural values are preserved and transmitted. In electronic books and projects of the network of public libraries, in cultural projects created through computer simulation and 3Dtechnologies, performances, products of mass culture, the predominantly postmodern view of man on the world is reproduced, which manifests itself in a plural, decentralized, rather chaotic sub-structure 'liveness.

E-culture products and socio-cultural projects are time-bound, they use a specific language. They complement the value diversity of modern culture. Postmodern art and literature relies on a new reading and understanding of traditional cultural values, which necessitates their reproduction in terms of pluralism.

Analysis of recent research and publications. Despite the significant scientific achievements in studying the general picture of the state and development of cultural values of the individual and society by Y. Bogutsky, I. Galyan, A. Kudryachenko, S. Pyazzin, V. Sivers, E. Schulz, C. Schwartz et al. $[1-2 ; 6 ; 8-9 ; 10]$ there is a need to study the cultural values of gifted personality in their traditional and plural representations.

In modern culturology the actualization of anthropological subjects is carried out by analyzing cultural practices capable of forming new man's images. O. Ovcharuk argues that "new types of reality (virtual, visual, and media reality) have opened up opportunities for the design and self-design of both the person himself and his image" $[5,12]$.

In the study of culture, K. Hearts proceeds from the fact that the main purpose of anthropology is to expand the boundaries of human discourse [4,22]. The scientist considers cultural resources as components of human thinking, and not an addition to it [4, 102-103].

The essence of Zh. Pyazh's views on the intellect lies in the statement that the latter, with its logical operations, is the most perfect form of adaptation, which, within the limits of the realization of the principle of freedom, allows us to reproduce reality in its entirety, freeing it from dependent subordination to the situational "here and now. " The process of intellectual exchange among individuals resembles a huge chess game of its size and a continuous game, where each action taken at one point entails a series of equivalent or complementary actions by the partners; by the law of grouping - is nothing, but a variety of rules that ensure player reciprocity and the coherence of their game. The formula of the law of the equinox can be realized under two conditions: 1) when a society does not deform an individual with coercion, but inspires and supports the free functioning of his mental activity; 2) when such a free functioning of the opinion of each individual, in turn, does not already distort the thoughts of other individuals or things, but is based on the reciprocity (interchange) between different activities [7, 224].

Harvard Professor G. Gardiner advanced the theory of plural intellect, which enriches traditional concepts, complementing their cultural context. Intellect generates abilities that are important in a particular cultural environment or community in order to solve problems and simulate their effects. Creating a cultural product is essential for such functions as mastering and communicating knowledge or expressing someone's views and 
feelings. "Products" can range from scientific theories up to musical works and even successful political campaigns "[3, 25].

The biological biases of a person to solve specific problems must be combined with cultural "feeding" in the corresponding field. Confirmation of this thought G. Gardiner invented various sources of knowledge about the normal development and development of gifted individuals; in the doctrines of the exclusive categories of people (including the wunderkinds); in intercultural interpretations of cognition, etc. [3, 25-26].

The purpose of the work is to determine the typological features of a gifted person from the standpoint of its participation in traditional and innovative cultural and artistic activities.

Presentation of basic materials. Human talent is manifested in a variety of abilities, including academic ones. The actuality of one or another activity is changing historically. In today's society, the importance of training in play, in particular - through computer games, is actualized. As a result of informatization of Ukrainian society, consumers have access to high-quality cultural services. According to the forecasts of IT specialists, the computer, in its computing power, will outperform a man about 2023.

An important role in increasing, preservation and popularization of cultural values are: institutes of creation and replication of products of artistic culture (creative unions, publishing houses, film studios, etc.); institutes for the development of artistic culture; institutes of preservation and restoration of products of artistic culture and artistic heritage (libraries, museums, theaters, restoration workshops, etc.); institutes and channels of propaganda of art, aesthetic education and education (advertising, mass media, Internet, art criticism, scientific art studies, etc.); artistic education and professional development of culture and arts. The system under consideration is the basis for traditional representations of cultural values. At the same time, it undergoes institutionalization.

Due to globalizational changes, Ukrainians are changing their attitudes towards family values. If earlier parents taught their children to get an education and profession in order to "firmly stand", then the changes that are taking place in the modern world require a young person to quickly adapt to new types of reality. It's hard to stand on your feet on a constantly moving treadmill. Earlier, the existence of cultural values was not limited in time. Works of art (paintings, vocal and choral works, choreographic productions, feature films and television series, etc.), products of technical aesthetics and design have not lost their relevance for a long time. Modern cultural projects and performances have a limited time of existence.

In view of the unceasing changes in contemporary cultural and artistic activity, we have developed a typology based on specialization, on the existing reciprocity between different types of cultural and artistic activity and on the spiritual, intellectual, creative and entrepreneurial abilities of a gifted personality. This allows us to deepen the notion of the presence of traditional and plural representations in the cultural values of a gifted personality.

To the first type of people we attributed the creators of cultural values. It is they, who are engaged in the creation of artistic culture and television products. These are artists, directors, scriptwriters, choreographers, designers, choirs, art critics, critics, and others. Among them there are many gifted personalities, who show their talents in original artistic works of painting, graphics and sculptures, artistic compositions, works of arts and crafts, traditional folk art, musical and literary works, etc. In their cultural values mostly traditional representations are appeared. In view of the unceasing changes in contemporary cultural and artistic activity, we have developed a typology based on the specialization, on the existing mutuality between different types of cultural and artistic activity and on the spiritual, intellectual, creative and entrepreneurial abilities of the talented personality. This allows us to deepen the notion of the presence of traditional and plural representations in the cultural values of a talented personality. In the process of civilization development of society, a category of consumers is allocated, which receive only ready-made samples, images and judgments about the world from multimedia means, therefore they are not able to select and independently process information. Along with this, among gifted individuals there are individuals, who perform a certain prognostic function in society, have the ability to fantasize and create futurological models of the future. We have categorized them into the second type - substantive figures. So M. Lossky called people directed their thoughts into the spiritual world, which contain predictions of future perfection. Substantivists select sectors of activity that include things that do not directly have practical significance, in particular those problems that are not on the agenda in real life. Such people ponder the problems of the spiritual world by creating certain models in it. Substantial figures are endowed with powerful intellectual and creative potential, have developed perceptual abilities and intuitions that influence the development of cultural values in the direction of humanism and rational perfection, in their traditional representations.

Representatives of the third type we called virtual designers. Just like substantive figures, they choose the field of activity and problems that are not on the agenda in real life. Often these models have a definite meaning for the real world. This happens, when the prior resolution of a particular problem turns out to be unsatisfactory and you need to look for a new one, often unpromising and unconventional. For example, in 20 years, a breakthrough in the processing of large amounts of data in Ukraine, in the complemented reality (technology of input in the field of perception of virtual elements), may occur in Ukraine. Then old models may not be able to withstand today's realities. In the creativity of gifted personalities engaged in the simulation of virtual reality plural representations of cultural values prevail. This is due to the fact that they originally created cultural products, and only later are the consequences of their impact on the individual and society appear. In virtual designers, the predominantly postmodern look, the plural, decentralized, and rather chaotic design of subjectivity is revealed. 
Representatives of the fourth type are members of the power structures, they are engaged in management in the socio-cultural sphere. Let's call them real action people, who give preference to methods repeatedly tested in practice. In the sphere of culture and art people of real action are engaged in the creation of the legislative framework, organization and development of material infrastructure of artistic culture (art market, galleries, auctions, production and demonstration sites). People of real action make efforts to preserve and increase the material and intangible cultural heritage of Ukraine, the habits and traditions of the Ukrainian people, and so on. Cultural values can be perceived by them as a means of maintaining the status of an individual and the prestige of Ukraine in the world. For example, in different countries of the world for the presidential residences they choose masterpieces of architectural art. The official residences of the President of Ukraine have a high cultural and historical value, and dignity represent our country in the world. These are such residences as: The Presidential Administration Building, in which architects S. Grigoriev and B. Zhezherin combines elements of the classical style and the Ukrainian Baroque; The Mariinsky Palace in Kyiv, built in 1750-1755, based on the model of the palace, designed by V. Rastrelli for $\mathrm{O}$. Razumovsky, where official state events are taking place (rewards, receptions, meetings of official delegations at the highest level, etc.); The house with chimeras, erected in 1901-1902, and executed in the early neo-Gothic style. In 2004, it was converted to premises for events with the participation of the President of Ukraine. The use of cultural heritage as a representation of the best achievements of Ukrainians in the world is an example of the traditional representation of cultural values.

People of real action often reject virtual models, developed by substantial actors and virtual designers. At the same time, life can change dramatically, and therefore models tested in practice can fail. The fate of society and the further development of national culture in such situations depends on the ability of people of real action and meaningful people to interact with each other, to see the pressing problems of a globalized society, and to determine the ways of their solution on the basis of foreseeing the consequences of their activities. If among the people of real action are gifted individuals of social and useful type, they are aware of the importance of such cooperation. The use of virtual models in the socio-cultural sphere can help to upgrade organizational and material infrastructure, lead to positive changes in its management, and influence the improvement of the welfare of producers and consumers of cultural products and services.

The fifth type is the traders with essential goods. As a rule, these are businessmen, entrepreneurs and sellers. They are engaged in the production and sale of cultural services and goods, and their timely delivery to consumers. Trade itself is an activity that eliminates barriers between producers and consumers. The interaction of substantial figures with dealers with essential goods is quite mediocre. The latter have to be in the middle of the most everyday, because a good trader always takes his lead from the fashion, season of the year, your income, he is a populist, who will be in tune with the state of the crowd. The trader conducts a culture-oriented policy aimed at meeting the urgent needs of consumers quickly. The style of his life is rather mundane, which affects the content of cultural values, which are primarily related to their higher ranking and the opportunity to obtain material profit. In spite of clear calculations of own expenses and profits, traders face the prevailing chaotic constitution of subjectivity, which is based on the disposable needs of the mass consumer of cultural services, and is presented in plural representations of cultural values.

The name of the last sixth type is a progressor borrowed from the Strugatsky brothers. It is a representative of a highly developed civilization, which has rooted in a civilization, which is at a lower level of development, and seeks to bring it to a higher level. His chosen style of life is marked by the material and spiritual unity of human activity, which creates, preserves and conveys the meanings, artifacts, values and ideals of human life. In a context of globalization, the values of a democratic society are spreading all over the world, which are implemented in accordance with the real needs and lifestyle of a modern person. The progressor is capable of broadcasting to the individual and society the standards of a highly developed civilization in the most holistic form. His cultural values are represented both in traditional and plural representations. Striving for perfection, he can not at the same time predict all the consequences of integrating the values of highly developed civilization into another national culture.

Conclusion. Based on the specialization and the existing reciprocity between different types of traditional and innovative cultural and artistic activities, the spiritual, intellectual, creative and entrepreneurial abilities of a gifted person involved in it, we identified six types of people: the creators of cultural values that create artistic culture and television products; Substantial figures, who perform a certain prognostic function in society; people of real action, who are involved in the organization and development of the material infrastructure of culture (in these three types cultural values are represented predominantly in traditional representations); virtual fashion designers, who display a predominantly postmodern view of the world and simulate virtual reality; merchants with essential goods engaged in the production of cultural services and goods, as well as timely delivery to consumers (these two types are dominated by plural representations of cultural values); a progression that seeks to tighten the cultural development of society to a higher level (its cultural values are represented both in traditional and plural representations). Defined in the research representations of the cultural values of gifted personality direct scientists to deepen the idea of self-identification of man in cultural and artistic activity. 
תimepamypa

1. Богуцький Ю. П. Українська культура в європейському контексті / за ред. Ю. П. Богуцького. Київ : Знання, 2007. 679 с.

2. Галян І. М. Ціннісні орієнтації як детермінанти розвитку моральної активності та морального самоудосконалення особистості // Моральна свідомість та самосвідомість особистості : монографія / за ред. М. Савчина, І. Галяна. Дрогобич : Ред.вид. відділ Дрогобицького державного педагогічного університету імені Івана Франка, 2009. 288 с.

3. Гардинер Г. Множинні інтелекти. Теорія у практиці: Хрестоматія / пер. с англ. Д. Купко, Р. Свято. Київ : Мегатайп, 2004. $288 \mathrm{c}$.

4. Гірц К. Інтерпретація Культур : Вибрані есе / пер. з англ. Київ : Дух і Літера, 2001. 542 с.

5. Овчарук О. Трансформація образу людини в культурних практиках Постмодерну // Вісник Національної академії керівних кадрів культури і мистецтва : наук. журнал. К. : ІДЕЯ ПРИНТ, 2018. № 4. С.12-16.

6. П'янзін С. Д. Цінність як духовно-практичний феномен. Рукопис: дис. на здобуття наук. ступеня канд. фрілос. наук: спец. 09.00.03. / Інститут філософрії НАН України. Київ, 2002.

7. Пиаже Ж. Психология интеллекта / Избранные психологические труды / пер. с англ. и фр. и вступ. статья В.А. Лекторского, В.Н. Садовского, Э.Т. Юдина. Москва : Международная педагогическая академия, 1994. 680 с.

8. Сиверс В.А. Понятие ценности как константы человеческого бытия // Totallogy. Постнекласичні дослідження. № 29. Київ : ЦГО НАН України, 2013. С. 168-180.

9. Сучасні європейські культурно-історичні цінності в контексті викликів глобалізації: монографія / кер. автор. колективу і науковий редактор д.і.н., професор А. І. Кудряченко, ДУ «Інститут всесвітньої історії НАН України». К. : Фенікс, 2014. 444 с.

10. Schultz E.A. Cultural Anthropology: A Perspective on me Human Condition. 5th Ed. L.; Toronto: Mayfield, 2001. 394 p.

11. Schwartz S. H. Values: Cultural and individual. In S. M. Breugelmans, A. Chasiotis, \& F. J. R. van de Vijver (Eds.), Fundamental questions in cross-cultural psychology. Cambridge, UK: Cambridge University Press, 2011. p. 463-493.

\section{References}

1. Bogutsky Yu. P. (2007). Ukrainian culture in the European context. Kyiv: «Znannya» [in Ukrainian]

2. Galyan I. M. (2009) Valuable orientations as determinants of development of moral activism and moral self-perfection of personality. / Moral consciousness and self-consciousness of the individual. Drogo-bich: Red-eye. Department of the Ivan Franko Drohobych State Pedagogical University [in Ukrainian]

3. Gardiner G. (2004) Multiple Intelligences. Theory in practice (transl. from eng. D. Kupko, R. Svyato). Kyiv: «Megatayp» [in Ukrainian]

4. Girts K. (2001) Interpretation of Cultures: Selected Essays (transl. from eng.) Kyiv: «Spirit and Liter» [in Ukrainian]

5. Ovcharuk O. (2018) Transformation of the image of a person in cultural practices of Postmodern // National Academy of Managerial Staff of Culture and Arts Herald. Kyiv. IDEA PRINT. [in Ukrainian]

6. Pyantsin S. D. (2002) Value as a spiritual and practical phenomenon. Manuscript. Institute of Philosophy of the National Academy of Sciences of Ukraine. Kyiv. [in Ukrainian]

7. Piaget J. (1994) Psychology of Intellect. Selected Psychological Works (transl. from eng. V.A. Lectorovsky, V.N. Sadovsky). Moscow. International Pedagogical Academy [in Russian]

8. Sivers A.A. (2013) The notion of value as the constants of human existence. Totallogy. № 29. Kiev: TsGO NAS of Ukraine [in Ukrainian]

9. Kudryachenko A.I. (Ed.) (2014) Contemporary European Cultural and Historical Values in the Context of the Challenges of Globalization. State University "Institute of World History of the National Academy of Sciences of Ukraine". K.: Phoenix [in Ukrainian]

10. Schultz E.A. (2001) Cultural Anthropology: A Perspective on me Human Condition. 5th Ed. L.; Toronto: Mayfield [in English]

11. Schwartz S. H. (2011) Values: Cultural and individual. In S. M. Breugelmans, A. Chasiotis, \& F. J. R. van de Vijver (Eds.), Fundamental questions in cross-cultural psychology. Cambridge, UK: Cambridge University Press [in English] 